\title{
THE DETERMINATION OF CALCIUM IN BIOLOGICAL FLUIDS BY FLAME PHOTOMETRY
}

\author{
BY \\ F. J. N. POWELL \\ From the Pathology Unit, St. James's Hospital, Leeds
}

(RECEIVED FOR PUBLICATION MARCH 18, 1953)

The use of flame photometers has greatly simplified and expedited the estimation of sodium and potassium. Calcium is one of the elements which it is possible to determine by flame photometry, but little advantage has been taken of this fact in biological work for a number of reasons.

The concentration of calcium in extracellular fluids is usually less than that of potassium; a given quantity of calcium in a coal gas-air or butane-air flame emits much less light than an equivalent quantity of potassium, and the emission is more readily interfered with by the presence of other ions than is that produced by either sodium or potassium. Flame photometers differ in the extent to which effects of interference are observed, but the commercial model marketed by the Evans Electroselenium Company* is singularly free from this trouble when sodium or potassium has to be estimated in a biological fluid. The same statement, unfortunately, cannot be made in the case of calcium. The interference filter supplied for calcium estimations with the EEL flame photometer gives no reading at all for sodium if it is present in concentrations not greatly in excess of the calcium present, but in normal serum there will be about 28 equivalents of sodium for one of calcium. In such a case the amount of sodium light passing through the filter will be sufficient to cause a serious error in the calcium reading. Moreover, so little calcium is present in serum that the maximum dilution which will give a reasonable galvanometer deflection at normal levels is about one in four. With this concentration so much protein is present that there is a serious danger of blocking the jet.

The difficulty caused by clogging by protein can be avoided by precipitating the proteins as described in a method devised for use with an American instrument (Severinghaus and Ferrebee, 1950). To overcome the difficulty of sodium interference the authors recommend the use of

* The scale referred to in this paper in Table I is the only one; now provided. standards containing sodium and potassium in concentrations equivalent to those in the unknown $\frac{\bar{g}}{0}$ This means that no urinary calcium can be esti-o mated until the sodium and potassium contents have been determined and the requisite calculation $\infty$ carried out. In the case of normal serum this is 0 admittedly not necessary, but it is none the less necessary in the case of any considerable deviation $\vec{z}$ from normal. Further, the accuracy of the pro-o cedure with the EEL model will be low because the light emitted by the calcium will be quite $\overline{0}$ a small proportion of the total light passing the filter.

Methods have also been described for use wifn the Beckmann flame photometer, which invo ashing of the serum with perchloric-nitric a产年 mixture (Kapuscinski, Moss, Zak, and Boyk. 1952 ; Mosher, Itano, Boyle, Myers, and Iseri, 1951). They do not appear to be suitable for application to the EEL instrument.

Methods commonly employed for the determin- $\overrightarrow{\bar{B}}$ ation of calcium by chemical means usually involve precipitation of the calcium as oxalate. Precipitation as phosphate has been employed (Roe and:Kahn, 1929) for serum, but involves removal of proteins, followed by precipitation, washing, andoestimation of the phosphate. This method is not?. applicable to urine.

In the oxalate methods the precipitate has to be separated, washed, and subjected to further treat-o ment either to convert it to the carbonate or oxide which is subsequently determined (Hamilton 1925: Trevan and Bainbridge, 1926; Fiske and Adams, 1931 ; Sobel and Sobel, 1939) or dissolvedo and the oxalate estimated either gravimetrically (McCrudden, 1911), gasometrically (Van Slyke and స్ Sendroy, 1929), colorimetrically (Sendroy, 1942) or. more usually, volumeirically (Kramer and Tis dall, 1921 ; Clark and Collip, 1925 : Shohl and Pedley, 1922). The Clark and Collip modifica tion of the Kramer and Tisdall permanganate titration is perhaps the most widely used methodo for the determination of serum calcium. This involves two washings of the oxalate precipitate 
and its subsequent solution and titration with 0.01 $\mathrm{N}$ permanganate. Not only is there opportunity for loss of the precipitate in the washing process but incomplete washing will lead to erroneously high values for calcium. There is evidence that the composition of the precipitate is not always constant (Sandell, 1944), and the end-point of the titration is extremely critical. A difference of $0.1 \mathrm{ml}$. of $0.01 \mathrm{~N}$ permanganate, which does not make a very marked difference in the colour of the titrated solution, makes a difference of $1 \mathrm{mg}$. per $100 \mathrm{ml}$. in the result. Precipitation as the picrolonate has been employed (Van Slyke and Kreysa, 1942 ; Cohn and Kolthoff, 1943), but this necessitates ashing of the serum, precipitation, isolation of the precipitate, and its gasometric or colorimetric determination.

In the case of urine larger quantities can be used, and the permanganate titration therefore becomes less critical. As uric acid also titrates with permanganate, and may be precipitated simultaneously with calcium oxalate, it is usually necessary to adopt a lengthy procedure to destroy the uric acid (Shohl and Pedley, 1922).

Flame photometry would therefore appear to possess great advantages even if a preliminary separation of calcium from a great excess of interfering substances is necessary. Complete removal of other ions is not required, so there will be no need for any washing of the precipitate with the possibility of loss in the washing, nor is the exact composition of the precipitate a matter of great importance, because the calcium is itself estimated. Precipitation as oxalate has advantages, because it is the basis of most of the figures in the literature ; it is usually applied in the presence of the serum proteins, and, if the $p \mathrm{H}$ is controlled, can be applied to urine without fear of simultaneous precipitation of magnesium. In addition, calcium oxalate is of exceedingly low solubility.

Unfortunately the oxalate ion has a depressant effect on the light emitted by calcium. If the precipitate is taken up in $\mathrm{HCl}$, not only will any $\mathrm{HCl}$ present in excess of that required just to combine with the calcium serve to lower the calcium reading, but so will the dissolved oxalate (Table I). The use of an oxidizing acid such as nitric to take up the precipitate will lessen the oxalate interference, but the acid will itself interfere. It was found that perchloric acid was most effective in removing the oxalate interference and in having the least depressant effect itself.

It is necessary to adjust the $\dot{p} \mathrm{H}$ for the oxalate precipitation in urine to between 4 and 5.6 if complete precipitation of calcium and none of magnesium is to be secured. McCrudden (1911) used a sodium acetate-acetic acid buffer to bring about this state of affairs. Since the ammonium ion causes no interference with the flame photometric determination of sodium and potassium with the EEL instrument (Collins and Polkinhorne, 1952) and less than any other cation examined in the case of calcium (Table I), ammonium

TABLE I

READINGS* ON LOWER SCALE OF EEL FLAME PHOTOMETER

\begin{tabular}{|c|c|c|c|c|c|}
\hline \multicolumn{5}{|c|}{ Substance Added } & Reading \\
\hline 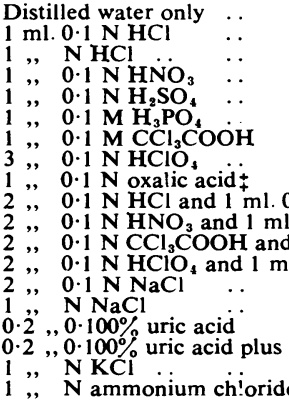 & $\begin{array}{l}\cdots \\
\cdots \\
\cdots \\
\cdots \\
\cdots \\
\cdots \\
0 \cdot 1 \mathrm{~N} 0 \\
\text { d. } 0 \cdot 1 \mathrm{~N} \\
\text { nl. } 0 \cdot 1 \mathrm{r} \\
\cdots \\
\cdots \\
1 \mathrm{ml} 0 \\
\cdots\end{array}$ & $\begin{array}{l}\cdots \\
\ldots \\
\ldots \\
\ldots \\
\ldots \\
\ldots \\
\cdots \\
\text { oxalic a } \\
\text { oxaiic } \\
0 \cdot 1 \mathrm{~N} \\
\text { N oxali } \\
\ldots \\
\ldots \\
0 \cdot 1 \mathrm{~N} \mathrm{H} \\
\ldots \\
\ldots\end{array}$ & $\begin{array}{l}\ldots \\
\ldots \\
\ldots \\
\ldots \\
\ldots \\
\ldots \\
\text { acid } \\
\text { ic acid } \\
\text { oxa'ic ac } \\
\text { lic acid } \\
\ldots \\
\ldots \\
\text { HCiO, } \\
\ldots \\
\ldots\end{array}$ & $\begin{array}{l}\cdots \\
\cdots \\
\cdots \\
\cdots \\
\cdots \\
\cdots \\
\cdots \\
\cdots \\
\cdots \\
\therefore i d \\
\cdots \\
\cdots \\
\cdots \\
\cdots \\
\cdots\end{array}$ & \begin{tabular}{|r}
$50 \dagger$ \\
50 \\
45 \\
40 \\
32 \\
8 \\
50 \\
51 \\
6 \\
24 \\
26 \\
20 \\
3.3 \\
50 \\
over 100 \\
45 \\
50 \\
56 \\
45
\end{tabular} \\
\hline
\end{tabular}

* The readings are given by $1 \mathrm{ml}$. of calcium chloride solution which contains $20 \mathrm{mg}$. per $100 \mathrm{ml}$. of calcium plus the additions in the lefthand column and the whole made up to $4 \mathrm{ml}$. with distilled water. The concentration of calcium in the fluid solution will be the same as that in the so!ution sprayed into the flame from an original unknown solution containing $10 \mathrm{mg}$. per $100 \mathrm{ml}$. of calcium when the procedure described in the test is followed.

† The sensitivity control is set so as to give this reading. All subsequent readings are taken with this setting.

$\ddagger$ Shaken up thoroughly before reading. Sprayed as a suspension.

salts would seem to be better suited as buffers for flame photometry than sodium salts. Moreover, since there is a fairly wide range of $p \mathrm{H}$ which is satisfactory in the present case, the convenience of the buffer rather than precision or buffering power was felt to be the chief consideration. No buffers are normally added to serum, but if the precipitating agent was incorporated into the buffer the procedure for urine would then consist simply of adding the buffer to the urine and the same reagent could be used for sera. An ammonium oxalate-oxalic acid mixture of $p \mathrm{H} 5$ was therefore chosen as being a sufficient buffer for the purpose, and one which made the determination of sodium and potassium possible on the supernatant from the calcium, a procedure of value when supplies of serum are limited.

\section{Method}

The determination of calcium in blood serum, cerebrospinal fluid, urine, bile, oedema fluid, etc., then 
becomes simply a matter of precipitating calcium as oxalate by means of an oxalic acid-ammonium oxalate mixture, centrifuging down the precipitate, and after decanting off the supernatant fluid, which may be used if necessary for the estimation of sodium and potassium, dissolving the precipitate in perchloric acid which is sufficiently concentrated to dissolve the precipitate but not sufficiently concentrated to lower the calcium reading. This solution is then sprayed into the flame photometer and its calcium content read. Rounded centrifuge tubes were found better than pointed ones, as they permitted more ready resolution of the precipitate. It was also found advantageous to have them graduated at $4 \mathrm{ml}$. The beakers supplied with the flame photometer were found rather too large for the quantities of fluid available, and similar beakers of the same height but about $5 \mathrm{ml}$. capacity were found more suitable. It was also found that heparinized blood plasma was not satisfactory unless the precipitation was carried out promptly after collection. Small particles of fibrin tend to form within a few hours of collection and spin down with the precipitate. They tend to block the jet and also cause the oxalate precipitate to lose its characteristic crystalline form and appear instead as a kind of protein oxalate complex which is extremely difficult to dissolve. If it is necessary to use heparinized plasma it is therefore advisable to remove proteins before precipitating the oxalate.

Solutions.-The following are required:

Ammonium Oxalate-Oxalic Acid, pH 5.0 M-0.1Oxalic acid, M-0.1, $10 \mathrm{ml}$.. and ammonium oxalate. M-0.1, $190 \mathrm{ml}$.

Perchloric Acid Approximately 0.05 N.-Perchloric acid $60 \%$ as supplied commercially, $0.83 \mathrm{ml}$., diluted to $100 \mathrm{ml}$. with distilled water.

Calcium Chloride, $5 \mathrm{mg}$. per $100 \mathrm{ml}$. calcium $(2.5$ $m E q$./litre). - This is made by dilution of a stock M-0.125 calcium chloride which is checked by estimating the chloride concentration. The stock solution is diluted 1 in 100 daily.

Procedure.-Two millilitres of serum are pipetted into a rounded centrifuge tube and $3 \mathrm{ml}$. of the oxalate buffer added. The contents of the tube are mixed and allowed to stand for 30 minutes. It is advisable but not essential to treat $2 \mathrm{ml}$. of a solution of calcium chloride containing $10 \mathrm{mg}$. calcium per $100 \mathrm{ml}$. similarly at the same time.

The tubes are then centrifuged for 10 minutes at a speed of at least 1,500 r.p.m. The supernatant fluid is decanted off and the mouth of the tube touched against a piece of filter paper or cotton-wool. Perchloric acid, $0.05 \mathrm{~N}$, is then added to the 4-ml. mark. the tube closed with a rubber stopper or with the thumb, and shaken vigorously for about 10 seconds. The contents are then transferred to a $5-\mathrm{ml}$. beaker.

A standard 12-ml. flame photometer beaker is filled with distilled water and another with freshly prepared $5 \mathrm{mg}$. calcium solution. The flame photometer is set with the calcium filter in position so that the distilled water reads zero and the calcium solution reads 50 on the lower scale of the flame photometer. The unknown solution in the $5-\mathrm{ml}$. beaker is then sprayed and the reading obtained noted.

Calculation.-The calculation is as below.

Calcium content in $\mathrm{mg}$. per $100 \mathrm{ml}$. $=\frac{\text { Reading }}{5}$

Calcium content in $\mathrm{mEq}$. per litre $=\frac{\text { Reading }}{10}$

The same procedure may be applied without change to urine, except that in cases where the urinary calcium level is expected to be high it may be advisable to use less than $2 \mathrm{ml}$.

\section{Results}

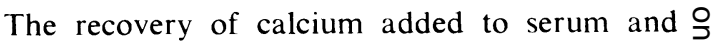
urine and the results of some parallel volumetric and flame photometric estimations are shown in $z$ Table II. The method described accurately estimates calcium added to serum and urine.

TABLE II

COMPARISON OF VOLUMETRIC AND FLAME PHOTG METRIC METHODS AND RECOVERY OF ADDED CALCIUP C

\begin{tabular}{|c|c|c|c|c|c|}
\hline & $\begin{array}{l}\text { Calcium } \\
\text { Added } \\
(\mathrm{mg} . \\
100 \mathrm{ml} .)\end{array}$ & $\begin{array}{c}\text { Calcium } \\
\text { Found } \\
\text { (mg. } / 100 \mathrm{ml} . \\
\text { Perman- } \\
\text { ganate } \\
\text { Titration) }\end{array}$ & \begin{tabular}{|c|} 
Per- \\
centage \\
Recovery
\end{tabular} & $\begin{array}{c}\text { Flame } \\
\text { Photometer }\end{array}$ & $\mid \begin{array}{r}\text { Per- } \\
\text { centage } \\
\text { Recovery }\end{array}$ \\
\hline Serum A & $\begin{array}{r}0 \\
2 \\
3 \\
4 \\
5 \\
6 \\
7 \\
10\end{array}$ & $7 \cdot 3$ & & $\begin{array}{r}7 \cdot 2 \\
9 \cdot 2 \\
9.9 \\
11 \cdot 2 \\
12 \cdot 6 \\
13 \cdot 4 \\
14 \cdot 4 \\
17 \cdot 2\end{array}$ & $\begin{array}{r}100 \\
90 \\
100 \\
108 \\
103 \\
103 \\
100\end{array}$ \\
\hline Serum B & 0 & $10 \cdot 2$ & & $10 \cdot 4$ & \\
\hline Serum C & 0 & $7 \cdot 7$ & & $7 \cdot 2$ & \\
\hline$\overline{\text { Serum D }}$ & 0 & $9 \cdot 8$ & & $10 \cdot 1$ & \\
\hline$\overline{\text { Serum } E}$ & $\begin{array}{r}0 \\
2 \\
6 \\
8 \\
10\end{array}$ & $\begin{array}{r}7.9 \\
9.8 \\
13.9 \\
15 \cdot 8 \\
18 \cdot 1\end{array}$ & $\begin{array}{c}95 \\
100 \\
98 \cdot 5 \\
102\end{array}$ & $\begin{array}{r}7 \cdot 7 \\
9 \cdot 7 \\
13 \cdot 4 \\
15 \cdot 7 \\
18 \cdot 0\end{array}$ & $\begin{array}{r}100 \\
95 \\
100 \\
103\end{array}$ \\
\hline Serum $F$ & $\begin{array}{r}0 \\
5 \\
10 \\
15\end{array}$ & $9 \cdot 5$ & & $\begin{array}{r}9 \cdot 4 \\
14 \cdot 8 \\
19 \cdot 7 \\
24 \cdot 0\end{array}$ & $\begin{array}{c}108 \\
93 \\
97.5\end{array}$ \\
\hline$\overline{\text { Serum G }}$ & 0 & $8 \cdot 6$ & & $8 \cdot 8$ & \\
\hline Urine $\mathrm{A}$ & $\begin{array}{r}0 \\
6 \\
8 \\
10\end{array}$ & $\begin{array}{l}20 \cdot 0 \\
25 \cdot 3 \\
28 \cdot 5 \\
29 \cdot 2\end{array}$ & $\begin{array}{c}88 \cdot 5 \\
106 \\
92\end{array}$ & $\begin{array}{l}20 \cdot 7 \\
25 \cdot 3 \\
28 \cdot 7 \\
30 \cdot 2\end{array}$ & $\begin{array}{r}77 \\
100 \\
95\end{array}$ \\
\hline$\overline{\text { Urine } B}$ & $\begin{array}{r}0 \\
5 \\
10 \\
15\end{array}$ & $15 \cdot 1$ & & $\begin{array}{l}15 \cdot 1 \\
20 \cdot 2 \\
24 \cdot 6 \\
29 \cdot 6\end{array}$ & $\begin{array}{r}102 \\
95 \\
98\end{array}$ \\
\hline \multicolumn{3}{|c|}{ Mean recovery } & 97.4 & & 98.4 \\
\hline
\end{tabular}




\section{Summary}

The advantages of flame photometry as a method of estimating calcium are discussed.

A simple, rapid method for the determination of calcium in body fluids is described.

The results of permanganate titrations and flame photometry agree closely.

The method accurately estimates calcium added to serum or urine.

I am indebted to Dr. D. MacKinnon for helpful advice, also to Dr. F. M. Parsons for advice and for making some of the checks of the method possible, and particularly to Dr. W. Goldie for valuable advice and assistance in the preparation of the material for publication.

\section{REFERENCES}

Clark, E. P., and Co!lip, J. B. (1925). J. biol. Chem., 63, 461

Cohn, G., and Kolthoff, I. M. (1943). Ibid., 147, 705.

Collins, G. C., and Polkinhorne, H. (1952). Analyst, 77, 430.

Fiske, C. H., and Adams, E. T. (1931). J. Amer. chem. Soc., 53, 2498.

Hamilton, B. (1925). J. biol. Chem., 65, 101.

Kapuscinski, V., Moss, N., Zak, B., and Boyle, A. J. (1952). Amer. J. clin. Path., 22, 687.

Kramer, B., and Tisdall, F. F. (1921). J. biol. Chem., 47, 475.

McCrudden, F. H. (1911). Ibid., 10, 187.

Mosher, R. E., Itano, M., Boyle, A. J., Myers, G. B., and Iseri, L. T. (1951). Amer. J. clin. Path., 21, 75.

Roe, J. H., and Kahn, B. S. (1929). J. biol. Chem., 81, 1.

Sandell, E. B. (1944). Colorimetric Determination of Traces of Metals. Interscience, New York.

Sendroy, J., Jr. (1942). J. biol. Chem., 144, 243.

Severinghaus, J. W., and Ferrebee, J. W. (1950). Ibid., 187, 621.

Shohl, A. T., and Pedley, F. G. (1922). Ibid., 50, 537.

Sobel, A. E., and Sobel, B. A. (1939). Ibid., 129, 721.

Trevan, J. W., and Bainbridge, H. W. (1926). Biochem. J., $20,423$.

Van Slyke, D. D., and Kreysa, F. J. (1942). J. biol. Chem., 142, 765. and Sendroy, J., Jr. (1929). Ibid., 84, 217. 